International Journal of Instruction e-ISSN: 1308-1470 • www.e-iji.net

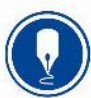

January $2019 \bullet$ Vol.12, No.1

p-ISSN: 1694-609X

pp. $959-976$

Received: $23 / 07 / 2018$

Revision: 01/10/2018

Accepted: 06/10/2018

OnlineFirst: $10 / 12 / 2018$

\title{
A Meta-Summary of Qualitative Findings about STEM Education
}

\section{Sedat Kanadlı}

Asst. Prof., Mersin University, Education Faculty, Turkey, skanadli@mersin.edu.tr

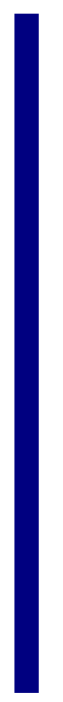

The purpose of this meta-summary study is to determine the preponderance findings about the contribution of STEM education to the dimensions of the science curriculum and the learning-teaching process, its limitations and applicability by bringing together the studies that examine the views of teachers and students participating on STEM education. For this purpose, 22 research reports collected according to particular criteria from the literature were included in this meta-summary study. The frequency effect sizes of the data of the research reports were calculated and the frequency effect size was reported to be higher than $15 \%$. As a result of the meta-summary study, 31 expressions were conceptualized under the themes of (i) the contribution of STEM education to knowledge, skills and affective dimension, (ii) contribution of STEM education to Science-Engineering-Technology-Society-Environment context, (iii) contribution of STEM education to learning-teaching process and (iv) the limitations and the recommendations on applicability of STEM education. It was determined that the most important contributions of the STEM education to science curriculum dimensions were as following; (i) appropriate for physics subjects, (ii) developing life skills, (iii) attracting the attention of the students, (iv) creating career awareness and (v) learning by fun.

Keywords: STEM education, qualitative finding, meta-summary, science curriculum, frequency effect size

\section{INTRODUCTION}

Education is in a mutual interaction with science and technology. Developments in science and technology influence the education, and vice versa. Therefore, it can be said that today's rapid-developments in science and technology force educational organizations not only to raise individuals equipped with knowledge but also to educate individuals who know how to access the knowledge and produce new information by using the knowledge they have obtained. Educational organizations educate individuals with the knowledge and skills they have developed through teaching programs. For this reason, the Turkish Ministry of National Education [MoNE] aims to give some knowledge and skills to the students in the curriculums developed since 2005. As a matter of fact, MoNE adopted a program design approach based on an interdisciplinary

Citation: Kanadl1, S. (2019). A Meta-Summary of Qualitative Findings about STEM Education. International Journal of Instruction, 12(1), 959-976. https://doi.org/10.29333/iji.2019.12162a 
approach to instructing individuals who are able to produce knowledge and use it functionally in life and have 21st-century skills through the curriculum that was put into practice in the 2017-2018 academic year. With this approach, the science curriculum was formed from knowledge, skill, affective dimensions and Science-EngineeringTechnology-Society-Environment context (MoNE, 2017). The knowledge dimension consisted of the earth and the universe, creatures and life, physical phenomena, matter and nature themes. Skill dimension consisted of scientific-process skills, life skills, and engineering and design skills. The affective dimension consisted of attitude, motivation, value and responsibility sub-dimensions. The Science-Engineering-Technology-SocietyEnvironment context also composed of socio-scientific subjects, nature of science, the relation of science engineering and technology, the relation of science and technology with society, the awareness of sustainable development, and career consciousness subdimensions in which knowledge, skill, and affective dimensions were associated. In this way, MoNE has integrated a holistic approach, called STEM, in which the students will transform the knowledge and skills acquired in science and mathematics into an engineering product using technology.

STEM is an acronym created by putting together the initials of science, technology, engineering and mathematics in order to describe the education or professional practices in these fields (McDonald, 2016). This acronym is translated into Turkish as FeTeMM. Though not an absolute compromise on the definition of STEM education, some researchers attempt to integrate some or all of the fields of science, technology, engineering and mathematics, or some part of a class, a unit or course, based on the relationship between the subject matter and real-life problems (Moore et al., 2014) while some researchers define it as the approach of exploring the learning and teaching among two or more STEM domains or between STEM domains and other courses (Sanders, 2009). Kelly and Knowles (2016) defined STEM as an approach in which students are taught the content of two or more STEM domains in applications that relate science, technology, mathematics, and engineering in contexts involving real-life problems to enrich their learning. According to these definitions, STEM education is employed as (i) it involves an application that relates at least two of the science, technology, mathematics and engineering fields, (ii) these fields are brought together in a context based on real-life problems, and (iii) it helps teaching students the subject-matters or enriches their learning.

The purpose of STEM education is, by providing students with STEM topics and practices, developing positive attitudes towards STEM, and enabling them to be lifelong learners, (i) to increase the number of students who choose STEM fields as a profession, (ii) to expand the workforce with STEM skills, and (iii) to increase the number of students who are STEM literate (National Research Council [NRC], 2011). In other words, students are expected to make a career in STEM areas to move from the consumer position to the producer position by acquiring some skills through STEM education. Examining these aims, it can be said that the aim of creating a workforce through STEM education is political while making students become STEM literates serves a pedagogical purpose. The STEM concept is the outcome of the political agenda of the National Science Foundation [NFS] for the first time in the late 1990s in the USA 
as a professional and economic necessity in order to increase the number of students who prefer STEM fields (Blackley \& Howell, 2015). According to Blackley and Howell (2015), the STEM was first seen as individual disciplines, then it was taught with more emphasis on other fields because of the lack of engineering field in the curricula, and later, upon determining how to include the engineering field, "STEM Education" concept emerged, and finally, it was followed by the concept of "Integrated STEM Education" after the relations between these four fields were identified. In recent years, the STEAM platform has been formed with the addition of the Art component to integrated STEM education in order to develop creativity and innovation aspects (Land, 2013). In addition, education of science, technology, engineering, arts, mathematics, entrepreneurship and design (STEAMED) has been discussed along with the addition of the components that emphasize the design (D) of the product and the entrepreneurship (E) necessary for marketing the product (Albert, 2016).

In STEM education, there are two approaches to integration of science and mathematics fields into the engineering field as context and content (Moore \& Smith, 2014): In context integration, engineering design is seen as a motivating tool for teaching the content of mathematics and science fields, whereas for integration of content, engineering skills form a part of the learning objectives together with science and mathematics content. Based on these integration approaches, the STEM curricula should involve (i) a process and product based evaluation (ii) in a digital format (iii) using inquiry, problem and performance based and constructivist teaching approaches (iv) with an interdisciplinary approach and understanding by design (Lantz, 2009). Pedagogical applications such as inquiry-based teaching, argumentation, digital learning, programming and robotics are generally employed during the implementation of curricula (McDonald, 2016). In inquiry-based teaching, students are expected to define daily problems, form hypotheses, collect data, evaluate hypotheses, generalize them, and assess themselves in this process (Kauchak \& Eggen, p. 369). In the argumentation, students are required to participate in a scientific discussion, make a claim based on the facts, justify and support these claims, and specify the conditions under which the claims will be correct (Toulmin, 1958) while in digital learning, they are to use mobile devices such as mobile phones, tablets and notebooks in the learningteaching process. In coding and robotics, students are asked to program a robot using one of various coding languages.

The integration of technology and engineering into school education through various inclass pedagogical practices has been set forth as an effective tool for enriching student learning and enhancing student achievement in STEM domains (Brophy, Klein, Portsmore \& Rogers, 2008). Indeed, in the literature review conducted by the NRC (2014) on the impact of integrated STEM education on learning outcomes, it was determined that STEM education has significant benefits for students and educators. According to this, learning outcomes of STEM education for students are specified as (i) increasing academic achievement, (ii) improving the 21 st century skills, (iii) augmenting the number of students who are taking courses in STEM fields, continuing education and graduating, (iv) increasing STEM workforce, (v) developing the interest in STEM and also STEM identity, and (vi) improving the ability to convey understanding between 
STEM domains. The learning outcomes for the educators are (i) the use of instructional strategies that engage students in scientific inquiry or engineering design, and (ii) the enhancement of STEM and pedagogical content knowledge.

When the studies conducted to reveal the effect of STEM education are examined on the basis of methodology, it is seen that there are quantitative (Gökbayarak \& Karışan, 2017; Cotabish, Dailey, Robinson \& Hunghes, 2013; Robinson, Dailey, Hughes \& Cotabish, 2014; Tati, Firman \& Riandi, 2017), qualitative (Ayar, 2015; Stubbs \& Myers, 2015; Holmquist, 2014; Yıldırım \& Türk, 2018) and mixed-method studies (Acar, Tertemiz, Taşdemir, 2018; Yıldırım \& Selvi, 2016; Robinson, 2016; Poole, 2016) in the literature. Quantitative researches are usually prepared with quasiexperimental designs, and the effect of STEM education on various variables (academic achievement, attitude, etc.) is examined by giving STEM education to the experimental group and traditional education to control group. Qualitative research is mostly prepared by the case study approach and the participants' opinions on the applied STEM education are examined. In the mixed method, the effect of STEM education on the quantitative dimension is investigated by the quasi-experimental design and the opinions of experimental group as to the effects of the STEM education are taken on the qualitative dimension.

There are also meta-synthesis studies in the literature that determine the characteristics of STEM education (Nite, Capraro, Capraro \& Bicer, 2017) and the effect of STEM education on academic success, skills, and attitude (Yildırım, 2016). In the metasynthesis study conducted by Nite et al. (2017), 57 individual studies were categorized in terms of their characteristics as reform-based learning and teaching, informal education, teacher factors and technology use. Reform-based applications cover the inquiry-based instruction, engineering design, project-based instruction, problem-based instruction, and applied activities. It was determined in the category of teacher factors that teachers' field knowledge increased most with STEM education. It was revealed through the informal STEM education that the students' interest in the STEM fields increased, they had an increased desire to acquire a profession in these areas and developed positive attitudes. It was determined in the meta-synthesis study conducted by Yildırım (2016) that there was a strong match between the principles of STEM education and the international comparison exams, and that STEM education had a positive effect on the academic achievement and attitudes of the students and that STEM education principles strengthened the creativity and problem-solving skills of students. Different from these meta-synthesis studies, this meta-summary study aims to determine how important and widespread the contribution of STEM education to various learning outcomes is by calculating the frequency effect sizes of qualitative findings. Thus, this meta-summary study is considered to be important in terms of leading to applications and new researches to be conducted in the field of STEM education.

The purpose of this meta-summary study is to determine the preponderance findings about the contribution of STEM education to the dimensions of the science curriculum and the learning-teaching process, its limitations and applicability by bringing together 
the studies that examine the views of teachers and students participating on STEM education. For this purpose, the answers to the following questions were searched:

1. What is the contribution of STEM education to knowledge, skills and affective dimensions?

2. What is the contribution of STEM education to Science-Engineering-TechnologySociety-Environment context?

3. What is the contribution of STEM education to the learning-teaching process?

4. What are the suggestions on the limitations and applicability of STEM education?

\section{METHOD}

In this study, a qualitative meta-summary method, which is a kind of research synthesis, was used. The qualitative meta-summary is a quantitative sum of qualitative findings in the form of a thematic summary or questionnaire data on any research topic (Sandelowski and Barroso, 2007, p.151). In this method, the findings obtained from the qualitative studies conducted on the same subject area are drawn together and the effect size of each finding is calculated. In this way, it is aimed to make more interpretations by determining the prevalence and importance of the findings (Onwuegbuzie, 2003). The reason for the use of the qualitative meta-summary method in this study is that the studies carried out on STEM education are mostly qualitative thematic. The qualitative meta-summary method involves the stages of $(i)$ the extraction of relevant findings from reports, (ii) editing findings, (iii) grouping findings under common themes, (iv) abstracting findings and $(v)$ calculating effect size (Sandelowski and Barroso, 2007, p. 152).

\section{Literature Search Strategies}

Google Scholar, ULAKBIM, ERIC and EBSCO databases were searched to reach the studies conducted and published about STEM in Turkey. The search was performed between March 2018 and April 2018, with a complementary search in May 2018. Key concepts such as "FeTeMM", "STEM", "FeTeMM views", "STEM views", "FeTeMM activities", "STEM activities", "Design-based science education", Engineering designbased science education " were entered in Turkish and English during the search process. By examining the reference parts of related studies conducted via content analysis and meta-synthesis, it was checked whether there were studies that could not be reached. As a result of the search, 334 studies carried out about STEM in Turkey were reached. After identical copies of these studies were removed, the titles and abstracts of 225 studies were examined. 158 of these studies were excluded for the reasons such as incomplete text, not including STEM activities and being book chapters. The remaining 67 studies were examined for suitability.

\section{Inclusion/Exclusion Criteria}

The studies included in this meta-summary study should be (i) carried out in Turkey prior to March 2018, (ii) with teachers and/or students of whose opinions about STEM 
education were asked after participating in the STEM education, (iii) employ one of the qualitative research design or, if quantitative, use qualitative data collection methods, and $(i v)$ be published in peer-reviewed journals.

The studies which (i) were published after March 2018, (ii) examined students' opinions without participation in any STEM training, (iii) employed only quantitative data collection tools (scale or questionnaire), (iv) did not separate the qualitative data from quantitative data or other elements of primary study, $(v)$ provided only raw data, and $(v i)$ were not published in peer-reviewed journals were not included in this study.

When 67 studies were examined according to these inclusion and exclusion criteria, it was determined that 17 studies used only quantitative methods, 20 studies received opinions without activities, the samples of 2 studies were taken from abroad, only robotics was applied in one of them, and 3 studies were not published in peer-reviewed journals. Accordingly, the remaining 24 studies were evaluated in terms of quality.

\section{Evaluation of Quality of the Studies}

Scoring system developed by Pulye, Gagnon, Griffiths and Lafleur (2009) was used to evaluate the quality of qualitative studies. In this scoring system, studies are scored as "existing"( 1 point) or "lacking" (0 points) in terms of purpose and research questions, the research approach and methods, the context of the research, the sample, data collection tools and analysis methods. Then, the quality score of the study is calculated by the formula [(The number of existing criteria)/(Total number of criteria)] x100. In this study, the evaluation was performed by adding "partially existing" ( 0.5 points $)$ to the scoring system. According to this, the quality score was calculated by the formula [(the score of the study)/ (Total score)] x100. The studies with a quality score below $50 \%$ were not included. As a result of the evaluation, two studies with a quality score of less than $50 \%$ were not included. The flow chart for the inclusion process is given in Figure 1. 


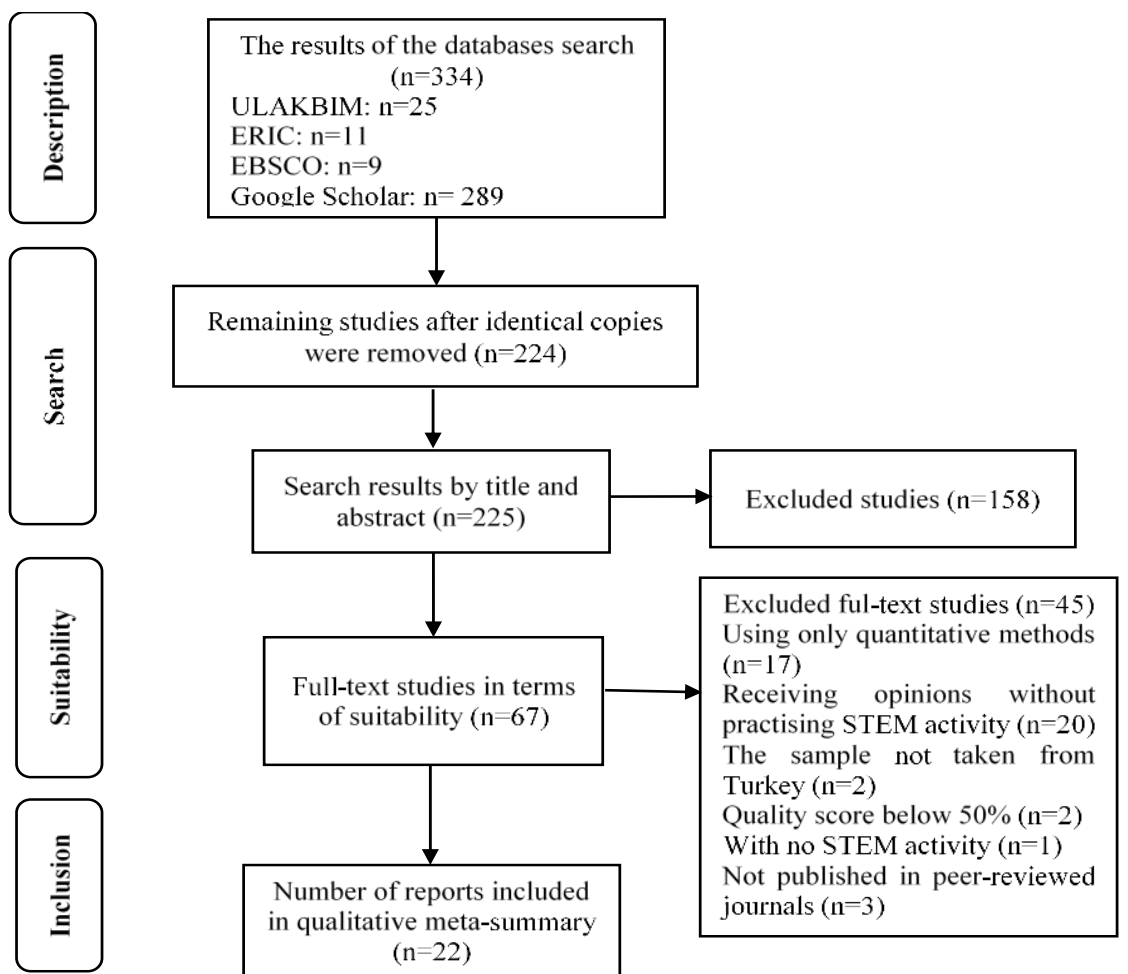

Figure 1

Flow chart for the inclusion process of the studies

\section{Coding of the Characteristics of the Studies}

The studies included in this meta-summary study were coded in terms of the author's name and date of publication, brief purpose of the study, qualitative approach or method used in the study, sample and size of the study, data collection tools and data analysis method.

When the 22 studies included in the meta-summary were examined in terms of purpose, 15 of them aimed to determine the participants' views of the process, three of them to identify the participants' evaluations of the process, two of them to reveal the participants' perceptions of the process, and the remaining two to determine the effect of this process on the participants' perceptions and perspectives. 11 of the studies were conducted with case study, six with qualitative descriptive, two with action research, two with mixed research, one with experimental and one with phenomenology method. The study group of the studies included consists of a total of 699 people (193 secondary and high school students, 463 teacher candidates and 31 teachers). As a qualitative data collection tool, semi-structured interview form was used in 11 of them, open-ended question form in nine of them, observation and interview in one of them, and activity evaluation form in one of them. Lastly, as a qualitative data analysis method, content 
analysis was employed in 20 of them, descriptive analysis in one of them and constant comparison in one of them.

\section{Extracting the Findings from Reports, Organizing and Grouping}

In the context of this study, the STEM activity was defined as an event in which the participants transformed the information they learned in science and mathematics into an engineering product using technology. All the findings including the views of those who participated in the STEM activities performed in accordance with this definition were extracted from 22 reports and written down on a Word document. When the findings were extracted from the reports, they were sorted out from; (i) code definition tables, (ii) direct quotations of the participants, (iii) the references to other studies, and (iv) interpretations of the researchers. As a result of this sorting process, a total of 390 expressions regarding the STEM education were obtained from 22 studies. These expressions were organized by entering them to a qualitative data analysis software and were grouped as the contributions and limitations of STEM education, and suggestions for the applicability of these education.

\section{Abstraction of the Findings and Calculation of their Effect Sizes}

In the abstraction process, the expressions having the same meaning were combined into a single expression. Thus, the fewest expressions representing all the findings from the research reports were obtained. Accordingly, the 390 statements drawn from the research reports were conceptualized under the themes of STEM education's contribution to the knowledge, skills, affective dimensions and the learning-teaching process, its limitations, and suggestions for its applicability. Following the conceptualization process, the frequency effect size was calculated to determine the preponderance of each expression. The frequency effect size is calculated by the ratio of the number of the reports containing the findings to the total number of the research reports. In this meta-summary study, 31 expressions were included, with a frequency effect size higher than $15 \%$.

\section{Validity and Reliability}

The descriptive, interpretive, theoretical and pragmatic validity types are improved to ensure validity in research synthesis (Sandelowski \& Barroso, 2007, p.232). The main idea of these validity types is negotiated validity (Belgrave \& Smith, 1995) and is based on the agreement. In order to achieve this, (i) the most important databases that publish research reports on STEM education were scanned at regular intervals, (ii) the search was conducted separately by two people using keywords, (iii) research reports obtained as a result of the search were compared and their suitability was discussed by evaluating them separately according to evaluation criteria and (iv) an expert with publications in STEM education was consulted on the suitability and usability of the findings obtained. In order to ensure reliability, $20 \%$ of the collected research reports were randomly selected and given to another person, and he was asked to extract the data from the research reports, to organize them and to conceptualize them according to the determined seven themes. Later on, discussion was made on the suitability of the results and an agreement was tried to be reached. 


\section{FINDINGS}

\section{Contribution of STEM Education to Knowledge, Skill and Affective Dimensions}

Participants expressed their opinion on the contribution of STEM education to knowledge dimension in 5 of 22 research reports included in this meta-summary study and to skills and affective dimension in 21 of them. These views are conceptualized in Table 1 by 15 expressions.

Table 1

Contribution of STEM education to the dimensions of the science curriculum

\begin{tabular}{lll}
\hline Dimensions and Expressions of the Science Curriculum & Freq. (N) & Effect Size (\%) \\
\hline STEM education is more appropriate for teaching or learning about subjects & 4 & 80 \\
related to learning of physical phenomena. & & 57.1 \\
\hline STEM education enhances the life skills of students. & 12 & 47.6 \\
STEM education develops psychomotor skills of students. & 9 & 42.9 \\
STEM education improves problem-solving skills. & 9 & 42.9 \\
STEM education enhances the scientific process skills of students. & 42.9 \\
STEM education develops the engineering and design skills of students. & 9 & 28.6 \\
STEM education improves students' imagination. & 6 & 28.6 \\
STEM education enhances the inquiry skills of students. & 6 & 23.8 \\
STEM education improves critical thinking skills. & 5 & 19.1 \\
STEM education develops 21 st-century skills of students. & 4 & 71.4 \\
STEM education provides students with the desire and motivation to learn, & 15 & 33.3 \\
attracting their attention and arousing interest and curiosity. & & \\
STEM education enables students to develop positive attitudes towards the & 7 & 28.6 \\
lessons. & & 23.8 \\
STEM education gives students the responsibility of their own learning and & 6 & 19.1 \\
their work. & & 5 \\
STEM education enhances students' courage and self-confidence by making \\
them feel competent.
\end{tabular}

As seen in Table 1, participants of STEM education expressed their opinions on the contribution of STEM education to knowledge dimension in one of 15 expressions, to skills dimension in nine of them, and to affective dimension in five of them. Participants stated, with an effect size of $80 \%(f=5)$, that STEM education is most suitable to teach or learn subjects about the learning of physical phenomena. When the contributions of STEM education to the skill dimension are examined, it is determined that this education contributes to the improvement of life skills at the maximum with an effect size of $57.1 \% \quad(\mathrm{f}=13)$. Following that, STEM education respectively develops psychomotor skills with an effect size of $47.6 \%(\mathrm{f}=10)$, problem solving, scientific process, engineering and design skills with an effect size of $42.9 \%$ ( $\mathrm{f}=9$ ), imagination and inquiry skills with an effect size of $28.6 \%(\mathrm{f}=6)$, critical thinking skills with an effect size of $23.8 \%(\mathrm{f}=5)$, and $21^{\text {st }}$ century skills with an effect size of $19.1 \%(\mathrm{f}=4)$.

Examining the contribution of the STEM education to the affective dimension, it is determined that this education attracts attention and interest, arouses curiosity, and provides learning desire and motivation with the effect size of $71.4 \%(\mathrm{f}=15)$. This is followed by developing positive attitudes towards the lessons with an effect size of 
$33.3 \%(f=7)$, giving students the responsibility with an effect size of $28.6 \%(f=6)$, enhancing students' self-confidence with an effect size of $23.8 \%(\mathrm{f}=5)$, and enabling students to become aware of both real life problems and their own knowledge and skills with an effect size of $19.1 \%(f=4)$.

\section{Contribution of STEM Education to Science-Engineering-Technology-Society- Environment (SETSE) Context}

The participants expressed their views on the contribution of STEM education to the science-engineering-technology-society-environment (SETSE) context in 21 out of 22 studies included in this meta-summary study. These views are conceptualized in Table 2 by two expressions.

Table 2

The Contribution of STEM education to the SETSE context

\begin{tabular}{lll}
\hline SETSE and Expressions & Freq. (N) & Effect Size (\%) \\
\hline $\begin{array}{l}\text { STEM education creates career awareness by helping students } \\
\text { choose professions in STEM fields. }\end{array}$ & 9 & 42.9 \\
$\begin{array}{l}\text { STEM education provides interdisciplinary relations by } \\
\text { integrating science, mathematics, technology and engineering. }\end{array}$ & 8 & 38.1 \\
\hline
\end{tabular}

As seen in Table 2, STEM education was found to contribute most to career awareness in the students with an effect size of $42.9 \%(\mathrm{f}=9)$ in SETSE context. Thereafter, it contributes to the relationship between the STEM fields with an effect size of $38.1 \%$ $(\mathrm{f}=8)$.

\section{Contribution of STEM Education to Learning-Teaching Process}

The participants expressed their views on the contribution of STEM education to the learning-teaching process in 21 out of 22 studies included in this meta-summary study. These views are conceptualized in Table 3 by seven expressions.

Table 3

The Contribution of STEM education to the learning-teaching process

\begin{tabular}{lcc}
\hline Elements and Expressions of the Curriculum & Freq. (N) & Effect Size (\%) \\
\hline STEM education enables students to learn by fun. & 13 & 61.9 \\
STEM education provides effective and permanent learning & 10 & 47.6 \\
$\begin{array}{l}\text { STEM makes students learn in cooperation (group interaction, sharing } 8 \\
\text { and socialization). }\end{array}$ & 38.1 \\
$\begin{array}{l}\text { STEM education facilitates student-centered education by enabling } \\
\text { learning by doing. }\end{array}$ & 8 & 38.1 \\
$\begin{array}{l}\text { STEM education provides active participation of students. } \\
\text { STEM education associates course content with life (living problems). } 6\end{array}$ & 6 & 28.6 \\
STEM education provides transfer of theoretical knowledge to & 5 & 23.8 \\
practice and concretization of information. & & \\
\hline
\end{tabular}

When the contribution of STEM education to the learning-teaching process is examined according to Table 3, it is seen that this education enables the students to learn by fun at the maximum with an effect size of $61.9 \%(\mathrm{f}=13)$. This is respectively followed by effective and permanent learning with an effect size of $47.6 \%(\mathrm{f}=10)$, cooperative and 
student-centered learning with an effect size of $38.1 \% \quad(\mathrm{f}=8)$, providing active participation and association of course content with daily life with an effect size of $28.6 \%(f=6)$, and concretization of information by transferring the knowledge with an effect size of $23.8 \%(\mathrm{f}=5)$

\section{Limitations of STEM Education and Suggestions for Its Applicability}

Participants expressed their views on the limitations of STEM education in 14 of 22 studies included in this meta-summary study and on its applicability in 11 of them. These views are conceptualized in Table 4 by seven expressions.

Table 4

Limitations of STEM Education and Suggestions for Its Applicability

\begin{tabular}{lll}
\hline Limitations, Suggestions and Expressions & Freq. (N) Effect Size (\%) \\
\hline The preparation and implementation of STEM education requires time. & 14 & 100 \\
It is costly because of the need for adequate equipment and materials for the & 11 & 78.6 \\
implementation of STEM education. & 5 & 35.7 \\
The preparation and implementation of STEM education is difficult. & 35.7 \\
STEM education does not relate to curricula and the test-oriented education & 5 & \\
system. & 4 & 28.6 \\
STEM education cannot be applied in crowded classes. & 45.5 \\
In-service training should be provided in the form of seminars, conferences or & 5 & \\
workshops to increase the knowledge and skills of teachers on STEM education. & \\
Material support should be provided for the implementation of STEM education. 5 & 45.5 \\
\hline
\end{tabular}

As seen in Table 4, participants in the STEM education gave an opinion on the limitations of these activities in five of these seven expressions and on their applicability in two of them. When the limitations of STEM education are examined, it is found that the preparation and implementation of STEM education requires time at the maximum with an effect size of $100 \%$ ( $\mathrm{f}=14)$. It is respectively followed by the high cost because of the need for adequate equipment and materials with an effect size of $78.6 \%(f=11)$, difficulty to prepare and practice it and having no relation to the education system with an effect size of $35.7 \%(\mathrm{f}=5)$, and inapplicability in crowded classes with an effect size of $28.6 \%(\mathrm{f}=4)$.

Examining the participants' suggestions to improve the applicability of STEM education according to Table 4, it is most suggested that the teachers should be given in-service training such as seminars, conferences or workshops, and provided with material support at the maximum with an effect size of $45.5 \%(\mathrm{f}=5)$.

\section{DISCUSSION}

It was aimed in this study to determine the importance and the preponderance of the opinions of teachers, students and teacher candidates on the contributions, limitations, and applicability of STEM education by meta-summary method. Accordingly, 390 expressions were extracted from 22 research reports, and 31 expressions with a frequency effect size greater than $15 \%$ were abstracted. The contribution of STEM education to knowledge ( 1 expression), skills (9 expressions) and affective (5 expressions) dimensions of science curriculum and to SETSE context (2 expressions) was abstracted with a total of 17 expressions while its limitations were abstracted with 2 expressions, and the suggestions for its applicability with 2 expressions. 
When the contribution of STEM education to the knowledge dimension of the curriculum was examined, it was found most appropriate for physics subjects covered in physical phenomena which give scientific information about different types of energy, the concepts of force and motion, their qualities and interactions. According to Eroğlu and Bektaş (2016), this is due to the fact that STEM activities are mostly performed in physics, whereas it is a misconception and STEM activities are also suitable for other subject areas of science. Examining the individual studies in the literature, though there are studies about the physics subjects which are widely involved in "physical phenomena" (Akdağ and Güneş, 2017; Çetin and Balta, 2017; Erdoğan and Çifçi, 2017; Özçelik and Akgündüz, 2018; Yıldırım and Selvi, 2017), various studies can also be seen in chemistry subjects that fall only into "matter and its nature" (Ercan, Bozkurt Altan, Taştan \& Dağ, 2016; Tarkin Çelikkıran \& Aydin Günbatar, 2017) and in biology subjects about "Living-beings and Life" (Sümen and Çalışıc1, 2016).

It was determined that STEM education contributes most to the development of life skills in the skills dimension. Life skills consist of sub-skills such as analytical thinking, decision-making, creative thinking, entrepreneurship, communication and teamwork (MoNE, 2013). In addition to life skills, it was widely revealed in the studies involved in this meta-summary study that STEM education also contributes to the development of psychomotor, scientific process, problem-solving, critical thinking, engineering and design, imagination, inquiry and $21^{\text {st }}$-century skills in students. The $21^{\text {st }}$-century skills actually contain most of the other skills. Although $21^{\text {st }}$-century skills are defined differently by different organizations and researchers, according to MoNE, they are composed of skills such as creativity and innovative thinking, critical thinking, problem solving, decision making, metacognition, communication, teamwork, literacy of information communication technologies and integration into the world (Çepni \& Ormanc1, 2018). The finding that STEM education contributes to skill development is paralleled by the result "STEM education strengthens the creativity and problem-solving skills of students" found in the meta-synthesis study conducted by Y1ldirım (2016, p.28). These skills are considered important in that they contribute to the development of cognitive, personal and interpersonal aspects of individuals and realize their potential by preparing them for the complex problems to be encountered in their lives (Ontario, 2016). In addition, the individuals who have these skills can more easily adapt to the qualifications expected in their professional lives (MoNE, 2016).

In affective dimension, STEM education was found most to attract the attention of the most students, to arouse interest and curiosity, and to provide them with the motivation and desire to learn. Motivation in education affects what students will pay attention to, how long they will keep their attention, and how much effort they will spend on learning (Smaldino, Lowther \& Russel, 2008, p.90). Therefore, the high motivation of the students can contribute to the high academic achievement of them (Kusurkar, Ten Cate, Vos, Westers \& Croiset, 2013; Alkan and Bayri, 2017). It is a common finding in the individual studies that, apart from motivation, STEM education enables students to develop positive attitudes, gives responsibility, increases self-confidence, and raises awareness of both real-life problems and themselves. In support for these findings, Yildirim (2016) and Nite et al. (2017) found in their meta-synthesis studies that STEM 
education contributes to the development of students' positive attitudes toward STEM domains. The fact that students develop positive attitudes toward STEM domains can also support their future careers in STEM fields (Koszalka, Wu \& Davidson, 2007).

When the contribution of STEM education to the Science-Engineering-TechnologySociety-Environment (SETSE) context was examined, it was found that it creates career awareness at the maximum. This finding shows parallelism with the result "STEM education has increased the desire to gain professions in STEM fields" in the metasynthesis study conducted by Nite et al $(2017$, p.43). One of the main purposes of STEM education is to increase the number of students who select STEM fields as a profession by expanding the workforce with STEM skills (NRC, 2011). Thus, it is possible to get a chance to be one of the countries that contribute to economic development and determine the future by meeting the needs of the qualified workforce of the business world (Turkish Industry and Business Association [TIBA], 2017). The other contribution of STEM education to the SETSE context is that it builds the relationship between the STEM fields. STEM education makes the interdisciplinary connection through real-life problems that can be solved by using the knowledge and skills of students in science, mathematics, technology, and engineering (Moore \& Smith, 2014). In this way, the conceptual learning of students in STEM fields increases (NRC, 2014) and their academic success improves (Y1ldırım, 2016).

It was determined that the most important contribution of STEM education to the learning-teaching process is that students can learn by fun. The reason for STEM education being fun may be that students are faced with a problem that can draw their attention and thus, they are actively involved in learning by doing within collaborative groups. Through STEM education, effective and permanent learning can be realized by transferring the contents of the lessons to real-life and making them concrete. To support these findings, according to NRC (2011), effective STEM education was determined to be the teaching that takes advantage of the interests and experiences of students, reveal what they know and build new knowledge on their knowledge, and encourage them for active participation. For this reason, it is proposed to use inquiry-based, problem-based, and performance-based and constructivist teaching approaches in order for the curriculum about STEM education to create such a learning atmosphere (Land, 2013).

It was determined that the most important limitations of STEM education are that it takes time to prepare and apply, and is costly as sufficient equipment and materials are required. In addition, the difficulty in preparing and practicing it, the unsuitability of curricula, and the inability to apply it in crowded classes were identified as the other common limitations of STEM education. According to the results of this study, it was suggested most that the teachers should be involved in professional development programs and provided with material support in order to increase the applicability of STEM education. In support of these findings, it was determined in the study by Siew, Amir, and Chong (2015) that the difficulties encountered in STEM education are the inadequate experience of teachers, high cost, poor material and the duration. It was suggested in the same study that, in order to overcome these problems, teachers should be given STEM-based project preparation training, group activities are to be done, easy- 
accessible and recycled materials should be preferred, and STEM projects should be done outside of school hours.

\section{RECOMMENDATION AND LIMITATION}

As a result of this meta-summary study, it can be suggested that (i) STEM education should be given not only in the field of physics but also in other areas, (ii) STEM education practices should improve the various skills of students, increase their motivation and teachers should include such practices as they are entertaining, (iii) material support must be provided since the most important limitations of STEM training are time-consuming and costly, (iv) teachers should be given professional development programs to prepare STEM projects.

This meta-summary study is limited to qualitative research conducted in Turkey. To see the big picture, incorporating international literature or performing mixed-method research synthesis involving the synthesis of quantitative data by meta-analysis as well as meta-summary for the future research synthesis studies to be conducted may as well contribute to the field of study. In addition, primary studies included in this metasummary study are the researches that examine the STEM-education-related views of participants who received STEM education. It is suggested that future studies should be experimental studies examining the effect of STEM education on various learning outcomes, rather than taking opinions of participants.

\section{REFERENCES}

(*) marked studies involved in the meta-summary.

Acar, D., Tertemiz, N., \& Taşdemir, A. (2018). The effects of STEM training on the academic achievement of 4th graders in science and mathematics and their views on STEM training teachers. International Electronic Journal of Elemantary Education, 10(4), 505-513.

Albert, E. (2016). Color me STEAMED: Engaging girls in STEM education. Retrieved from http://panelpicker.sxsw.com/vote/60048.

Alkan, İ., \& Bayri, N. (2017). A Meta-analysis study on the relationship between motivation for science learning and science achievement. Ziya Gökalp Eğitim Fakültesi Dergisi, 32, 865-874.

Aslan-Tutak, F., Akaygün S., \& Tezsezen, S. (2017). Collaboratively learning to teach STEM: Change in participating pre-service teachers' awareness of STEM. H. $U$. Journal of Education, 32(4), 794-816. DOI: 10.16986/HUJE.2017027115

Ayar, M. C. (2015). First-hand Experience with engineering design and career interest in engineering: An informal STEM education case study. Educational Sciences: Theory \& Practice, 6, 1655-1675.

Baran, E., Canbazoğlu- Bilici, S., Mesutoğlu, C. \& Ocak, C. (2016). Moving STEM beyond schools: Students' perceptions about an out-of- school STEM education program. International Journal of Education in Mathematics, Science and Technology, $4(1), 9-19$. 
Belgrave, L. L., \& Smith, K. J. (1995). Negotiated validity in collaborative ethnography. Qualitative Inquiriy, 1, 69-86.

Blackley, S., \& Howell, J. (2015). A STEM narrative: 15 years in the making. Australian Journal of Teacher Education, 40(7). DOI:10.14221/ajte.2015v40n7.8.

Bozkurt-Altan, E., Yamak, H. ve Buluş-Kırıkkaya, E. (2016). A Proposal of the STEM Education for Teacher Training: Design Based Science Education. Trakya Üniversitesi Eğitim Fakültesi Dergisi, 6(2), 212-232.

Bozkurt-Altan, E., \& Ercan, S. (2016). STEM education program for science teachers: perceptions and competencies. Journal of Turkish Science Education, 13(Special Issue), 103-117.

Brophy, S., Klein, S., Portsmore, M., \& Rogers, C. (2008). Advancing engineering education in P-12 classrooms. Journal of Engineering Education, 97(3), 369-387.

Cotabish, A., Dailey, D. Robinson, A., \& Hunghes, G., (2013). The effects of a STEM intervention on elementary students' science knowledge and skills. School Science and Mathematics, 113(5), 215-226.

Çepni, S., \& Ormancı, Ü. (2018). Geleceğin dünyası.[The world of the future] S.Çepni (Yay. haz.). Kuramdan uygulamaya STEM eğitimi içinde (s.1-52). Ankara: Pegem

Çetin, A., \& Balta, N. (2017). Pre-service science teachers' views on STEM materials and STEM competition in instructional technologies and material development course. European Journal of Educational Research, 6(3), 279- 288.

Çınar, S., Pırasa, N., \& Palic- Sadoglu, G. (2016). Views of science and mathematics pre-service teachers regarding STEM. Universal Journal of Educational Research, 4(6), 1479-1487.

Çınar, S., Pırasa, N., Uzun, N., \& Erenler, S. (2016). The effect of Stem education on pre-service science teachers' perception of interdisciplinary education. Journal of Turkish Science Education, 13(Special Issue), 118-142.

Erdoğan, I., \& Çiftçi, A. (2017). Investigating the views of pre-service science teachers on STEM education practices. International Journal of Environmental \& Science Education, 12(5), 1055-1065.

Ercan, S., Bozkurt Altan, E., Taştan, B., \& Dağ, İ. (2015). Integrating GIS into science classes to handle STEM education. Journal of Turkish Science Education, 13(Special Issue), 30-43.

*Eroğlu, S., \& Bektaş, O. (2016) Ideas of science teachers took STEM education about STEM based activities.. Journal of Qualitative Research in Education, 4(3), 43-67. DOI:10.14689/issn.2148-2624.1.4c3s3m

Gökbayrak, S., \& Karışan, D. (2017). An investigation of the effects of STEM based activities on preservice science teacher's science process skills. Batı Anadolu Eğitim Bilimleri Dergisi, 8(2), 63-84.

Hacioğlu, Y., Yamak, H., \& Kavak, N. (2017). The opinions of prospective science teachers regarding STEM education: The engineering design based science education. GUJGEF, 37(2), 649-684. 
Holmquist, S. (2014). A multi-case study of student interactions with educational robots and impact on Science, Technology, Engineering, and Math (STEM) learning and attitudes(Graduate Theses and Dissertations). University of South Florida. Retrieved from http://scholarcommons.usf.edu/etd/5043.

Karahan, E., Canbazoglu-Bilici, S., \& Unal, A. (2015). Integration of media design processes in science, technology, engineering, and mathematics (STEM) education. Eurasian Journal of Educational Research, 60, 221-240. Doi: 10.14689/ejer.2015.60.15

Kauchak, D.P., \& Eggen, P.D. (2007). Learning and teaching: Research-based method $(5 E d)$. Boston: Pearson.

Keçeci, G., Alan, B., \& Kırbağ Zengin, F. (2017). STEM education practices with 5th grade students. Ahi Evran Üniversitesi Kırşehir Ĕ̆itim Fakültesi Dergisi (KEFAD), 18(Special Issue), 1-17.

Kelley, T. R., \& Knowles, J. G. (2016). A conceptual framework for integrated STEM education. International Journal of STEM Education, 3(1), 1-11.

Koszalka, T. A., Wu, Y., \& Davidson, B. (2007, October). Instructional design issues in a cross-institutional collaboration within a distributed engineering educational environment. In World Conference on ELearning in Corporate, Government, Healthcare, and Higher Education.

Kusurkar, R.A., Ten Cate, Th.J., Vos, C.M.P., Westers, P., Croiset, G. (2013). How motivation affects academic performance: A structural equation modelling analysis. $A d v$ in Health Sci Educ, 18, 57-69. DOI 10.1007/s10459-012-9354-3.

Land, M.H.(2013). Full STEAM ahead: The benefits of integrating the arts into STEM. Procedia Computer Science, 20, 547-552.

Lantz Jr, H.B. (2009). Science, Technology, Engineering, and Mathematics (STEM) Education. What Form? What Function? Report, CurrTech Integrations, Baltimore.

McDonald, C.V. (2016). STEM Education: A review of the contribution of the disciplines of science, technology, engineering and mathematics. Science Education International, 27(4), 530-569.

MoNE (2013). Science curriculum. Retrieved from https://ridvansoydemir.wordpress.com/2013-fen-bilimleri-ogretim-programi.

MoNE (2016). STEM Eğitim Raporu. Retrieved from http://yegitek.meb.gov.tr/www/meb-yegitek-genel-mudurlugu-stem-fen-teknolojimuhendislik-matematik-egitim-raporuhazirladi/icerik/719.

MoNE (2017). Draft science curriculum. https://bilimakademisi.org/wpcontent/uploads/2017/02/Fen-Bilimleri.pdf

Moore, T. J., Stohlmann, M. S., Wang, H. H., Tank, K. M., Glancy, A. W., \& Roehrig, G. H. (2014). Implementation and integration of engineering in K-12 STEM education. In Engineering in Pre-College Settings: Synthesizing Research, Policy, and Practices (pp. 35-60). Purdue University Press. 
Moore, T.J., \& Smith, K.A.(2014). Advancing the State of the Art of STEM Integration. Journal of STEM Education, 15(1), 5-10.

National Research Council [NRC]. (2011). Successful K-12 STEM education: Identifying effective approaches in science, technology, engineering and mathematics. Washington, DC: The National Academic Press.

National Research Council [NRC].(2014). STEM integration in K-12 education: Status, prospects, and an agenda for research. Washington: National Academies Press.

Nite, S. B., Capraro, M. M., Capraro, R. M., \& Bicer, A. (2017). Explicating the characteristics of STEM teaching and learning: A Meta-synthesis. Journal of STEM Teacher Education, 52(1), 31-53.

Özçakır Sümen, Ö., \& Çalışıcı, H. (2016). Pre-service teachers' mind maps and opinions on STEM education implemented in an environmental literacy course. Educational Sciences: Theory \& Practice, 16, 459-476.

Özçelik, A., \& Akgündüz, D. (2018). Evaluation of gifted/talented students' out-ofSchool STEM education. Trakya University Journal of Education Faculty, 8(2), 334351.

Poole, M. (2016). Growing STEM education on the playground: A case study of the factors that influence teachers' use of school gardens (Dissertations and Theses). Portland State University Paper 2723.

Pulye, P., Gagnon, M.P., Griffiths, F., \& Johnson-Lafleur, J. (2009). A scoring system for appraising mixed-method research, and concomitantly appraising qualitative, quantitative, and mixed-methods primary-level studies in mixed studies reviews. Int.J.Nurs.Stud, 46(4), 529-46. DOI: 10.1016/j.ijnurstu.2009.01.009

Onwuegbuzie, A.J. (2003). Effect sizes in qualitative research: A prolegomenon. Quality \& Quantity, 37, 393-409.

Ontario.(2016). $21^{\text {st }}$ century competencies. Foundation document for discussion. Retrieved from https://www.kslaring.no/pluginfile.php/57624/mod_page/ content/1/21stCentury\%20Competencies.pdf

Robinson, N. (2016). A case study exploring the effects of using an integrative STEM curriculum on eighth grade students' performance and engagement in the mathematics classroom (Dissertation). Georgia State University. Retrieved from http://scholarworks.gsu.edu/mse_diss/32.

Robinson, A., Dailey, D., Hughes, G., \& Cotabish, A. (2014). The effects of a sciencefocused STEM intervention on gifted elementary students' science knowledge and skills. Journal of Advanced Academics, 25(3), 189-213.

Sanders, M. (2009). STEM, STEM Education, STEMmania. The Technology Teacher, 68(4), 20-26.

Sandelowski, M., \& Barroso, J. (2007). Handbook for synthesizing qualitative research. New York: Springer. 
Siew, N. M., Amir, N., \& Chong, C. L. (2015). The perceptions of pre-service and inservice teachers regarding a project-based STEM approach to teaching science. SpringerPlus, 4(8), 1-20.

Smaldino, S.E., Lowther, D.L., \& Russell, J.D. (2008). Instructional technology and media for learning (9th ed). Upper Saddle River, NJ: Pearson Publications.

Stubbs, E.A., \& Myers, B.E. (2015). Multiple case study of STEM in school-based agricultural education. Journal of Agricultural Education, 56(2), 188-203. DOI: 10.5032/jae.2015.02188.

Tarkın Çelikkıran, A., \& Aydın Günbatar, S. (2017). Investigation of Pre-service Chemistry Teachers' Opinions about Activities based on STEM Approach. YYU Journal Of Education Faculty, 14(1), 1624-1656.

Tati, T., Firman, H., \& Riandi, R. (2017). The effect of STEM learning through the project of designing boat model toward student STEM literacy. Journal of Physics: Conference Series. DOI :10.1088/1742-6596/895/1/012157.

Taştan Akdağ, F., \& Güneş, T. (2017). Science high school students and teachers' opinions about The STEM Applications on the subject of energy. International Journal of Social Sciences and Education Research, 3(5), 1643-1656

Toulmin, S. (1958). The uses of argument. Cambridge: Cambridge University Press.

TIBA (2017). 2023'e doğru Türkiye'de STEM gereksinimi [The STEM requirements in Turkey toward 2023]. Retrieved from http://www.tusiadstem.org/images/ raporlar/2017/ ozet-bulgu.pdf

*Uğraş, M. (2017). Okul öncesi öğretmenlerinin STEM uygulamalarına yönelik görüşleri. [The views of preschool teachers about STEM practices] The Journal of New Trends in Educational Science, 1(1), 39-54.

Yildırım, B. (2016). An analyses and meta-synthesis of research on STEM education. Journal of Education and Practice, 7(34), 23-33.

Yıldırım, B. (2018). Research on teachers' opinions on STEM practices. Eğitimde Kuram ve Uygulama Araştırmaları Dergisi, 4(1) 42-53.

Yildırım, P. (2017). A qualitative stuy on integration of science, technology, engineering and mathematics (STEM). Atatürk Üniversitesi Kazım Karabekir Eğitim Fakültesi Dergisi, 35, 31-55.

Yıldırım, B., \& Türk, C. (2018). Pre-Service primary school teachers' views about STEM education: An applied study. Trakya University Journal of Education Faculty, $8(2), 195-213$.

Yıldırım, B., \& Sevi, M. (2016). Examination of the effects of STEM education integrated as a part of science, technology, society and environment courses. Journal of Human Sciences, 13(3), 3684-3695. 